\title{
Eksperimentasi Model Pembelajaran Kooperatif Tipe Think- Pair-Share (TPS) Berbantuan Metode Drill terhadap Hasil Belajar Matematika Ditinjau dari Keaktifan Belajar Siswa
}

\author{
Ismah, Merlinda Justine \\ Universitas Muhammadiyah Jakarta \\ Jl. KH. Ahmad Dahlan Cirendeu Ciputat Tangerang Selatan \\ Email: ismah.fr@gmail.com
}

\begin{abstract}
ABSTRAK
Tujuan penelitian ini adalah (1) Untuk mengetahui apakah hasil belajar matematika siswa yang mengikuti pembelajaran matematika model pembelajaran kooperatif tipe Think-Pair-Share (TPS) berbantuan metode Drill lebih baik daripada hasil belajar matematika siswa yang mengikuti pembelajaran hanya menggunakan metode Drill pada pokok bahasan kubus dan balok. (2) Untuk mengetahui apakah terdapat pengaruh antara keaktifan belajar matematika siswa terhadap hasil belajar matematika siswa pada pokok bahasan kubus dan balok. (3) Untuk mengetahui apakah terdapat interaksi antara pemakaian model pembelajaran dan keaktifan belajar matematika siswa terhadap hasil belajar matematika siswa pada pokok bahasan kubus dan balok. Penelitian ini menggunakan metode eksperimen semu. Penelitian dilaksanakan di SMP YAPIA Ciputat dengan subjek penelitian ini adalah kelas VIII A untuk kelas eksperimen satu dengan jumlah 32 siswa dan kelas VIII C untuk kelas eksperimen dua dengan jumlah 37 siswa. Teknik pengumpulan data yang digunakan adalah metode dokumentasi yang berupa foto kegiatan pembelajaran, metode angket konstruk untuk data keaktifan belajar matematika siswa, metode tes untuk data hasil belajar matematika siswa pada pokok bahasan kubus dan balok, dan lembar observasi. Teknik analisis yang digunakan adalah analisis variansi dua jalan dengan sel tak sama. Sebagai persyaratan analisis yaitu populasi berdistribusi normal menggunakan uji Lilliefors dan populasi bervariansi sama (homogen) menggunakan uji Fisher. Dari penelitian ini dapat disimpulkan bahwa: (1) hasil belajar matematika siswa yang mengikuti pembelajaran matematika dengan model pembelajaran kooperatif tipe Think-Pair-Share (TPS) berbantuan metode Drill lebih baik daripada hasil belajar matematika siswa yang mengikuti pembelajaran hanya menggunakan metode Drill pada pokok bahasan kubus dan balok ( $\mathrm{F} a=49,19>4,00=\mathrm{F}$ tabel pada taraf signifikansi 0.05). (2) keaktifan belajar siswa memberikan pengaruh terhadap hasil belajar matematika siswa pokok bahasan kubus dan balok ( $\mathrm{F} b=$ $9,85>3.15=\mathrm{F}$ tabel pada taraf signifikansi 0.05). (3) Terdapat interaksi antara model pembelajaran dengan keaktifan belajar matematika terhadap hasil belajar matematika pada pokok bahasan kubus dan balok $(\mathrm{F} a b=18,59>3.15=$ Ftabel pada taraf signifikansi 0.05).
\end{abstract}

Kata kunci: Pembelajaran kooperatif tipe TPS, Metode Drill, Keaktifan Hasil Belajar

\section{ABSTRACT}

The purpose of this study were (1) To determine whether the results of learning mathematics students who take mathematics learning cooperative learning model Think-Pair-Share (TPS) aided method Drill better than the results of learning mathematics students who take the learning only method Drill on the subject cubes and blocks. (2) To determine whether there is influence between the liveliness of mathematics learning of the results of students' mathematics learning on the subject of cubes and blocks. (3) To determine whether there is an interaction between the usage model of learning and students' learning activeness math mathematics learning outcomes of students on the subject of cubes and blocks. This study used a quasi-experimental methods. Research conducted in junior YAPIA Ciputat with this research subject is class VIII to class A single experiment with a number of 32 students and class VIII C for two experimental class with a number of 37 students. Data collection techniques used is a method of documentation in the form of photos of learning activities, the questionnaire method constructs for data activeness of students 'mathematics learning, the test method to the data of students' mathematics learning on the subject of cubes and blocks, and the observation sheet. The analysis technique used is a two-way analysis of variance with different cells. As requirements analysis that is normally distributed population using population bervariansi Lilliefors test and the same (homogeneous) using Fisher's exact test. From this study it can be concluded that: (1) the results of learning mathematics students who take mathematics learning with cooperative learning model Think-Pair-Share (TPS) aided method Drill better than the results of learning mathematics students who take the learning only method Drill on the subject discussion cubes and blocks $(\mathrm{Fa}=49.19>4.00=$ Ftabel at significance level 0.05). (2) students 'learning activeness influence on students' mathematics learning outcomes subject of cubes and blocks $(\mathrm{Fb}=9.85>=$ 3:15 Ftabel at significance level 0.05). (3) There is interaction between the model of learning by studying 
the activity of mathematics to mathematics learning outcomes on the subject of cubes and blocks $($ Fab $=$ 18.59> = 3:15 Ftabel at significance level 0.05).

Keywords: Cooperative learning type of TPS, Methods Drill, activeness Learning Outcomes

\section{Pendahuluan}

Komponen pokok pencapaian keberhasilan suatu bangsa salah satunya adalah pendidikan. Pendidikan merupakan salah satu kebutuhan sehingga tidak dapat dipisahkan dari kehidupan sehari-hari. Pendidikan dapat di mulai melalui pemahaman manusia yang berbeda-beda. Melalui pendidikan siswa dapat mengembangkan pengetahuan yang dimiliki secara luas. Proses terjadinya pendidikan umumnya berlangsung disekolah dan di lingkungan sekitar.

Pencapaian siswa memahami materi dengan baik akan terwujud dari pola belajar siswa. Siswa kurang menerapkan pola keaktifan dalam proses pembelajaran untuk menumbuhkan rasa ingin tahu yang lebih mengenai persoalan yang sedang dihadapi dan kurang memiliki keaktifan yang optimal untuk terus-menerus belajar. Berdasarkan fakta dilapangan pada saat peneliti melakukan Program Pemantapan Lapangan (PPL) tahun 2014, $70 \%$ di SMP YAPIA Ciputat kurang aktif dalam proses pembelajaran sehingga berdampak pada hasil belajar matematika yang kurang memuaskan. Hasil tersebut berdasarkan nilai matematika ulangan tengah semester siswa dengan KKM 70. Diharapkan model pembelajaran kooperatif think-pair-share berbantuan metode drill menjadi cara yang tepat untuk mengajarkanpokok bahasan kubus dan balok, yang dapat meningkatkan keaktifan belajarsiswa dan siswa dapat memperoleh hasil belajar atau nilai yang tinggi.

Menurut Slavin kooperatif menekankan pada tujuan dan kesuksesan kelompok, yang hanya dapat dicapai jika semua anggota kelompok mencapai tujuan atau penguasaan materi (Trianto, [8]). Sanjaya [5] mengemukakan pembelajaran kooperatif merupakan model pembelajaran dengan menggunakan sistem pengelompokan/tim kecil antara empat sampai enam orang yang mempunyai latar belakang kemampuan akademik, jenis kelamin, ras, atau suku yang berbeda (heterogen).

Model pembelajaran kooperatif tipe Think-Pair-Share pertama kali dikembangkan oleh Frang Lyman dan koleganya di Universitas Maryland (Slavin, [6]). Model pembelajaran kooperatif tipe Think-Pair-Share (TPS) atau berpikir berpasangan berbagi merupakan pembelajaran kooperatif yang dirancang untuk memengaruhi pola interaksi peserta didik. tenaga pendidik menggunakan langkah-langkah (1) Berpikir (thinking) yaitu tenaga pendidik mengajukan suatu pertanyaan atau masalah yang dikaitkan dengan pelajaran, dan meminta peserta didik menggunakan waktu beberapa menit untuk berpikir sendiri jawaban atau masalah (2) Berpasangan (pairing) yaitu tenaga pendidik meminta peserta didik untuk berpasangan dan mendiskusikan apa yang telah mereka peroleh 4-5 menit (3) Berbagi (sharing) yaitu langkah akhir, tenaga pendidik meminta pasangan-pasangan untuk berbagi dengan keseluruhan kelas yang telah mereka bicarakan.

Faizi [3] mengemukakan metode pembelajaran yang tidak tepat dapat berakibat pada terhambatnyaproses belajar siswa, bahkan gagalnya para siswa dlaam menangkap substansi ilmu yang diajarkan. Yamin [12] menyebutkan metode pembelajaran berfungsi sebagai cara untuk menyajikan, menguraikan, memberi contoh, dan memberi latihan kepada peserta didik untuk mencapai tujuan tertentu.

Winarno Surachman mengemukakan Latihan atau berlatih merupakan proses belajar dan membiasakan diri agar mampu melakukan sesuatu Metode latihan pada umumnya digunakan untuk memperoleh suatu ketangkasan atau keterampilan dari apa yang telah dipelajari. Drill secara denotatif merupakan tindakan untuk meningkatkan keterampilan dan kemahiran serta dapat mengembangkan sikap dan kebiasaan (Asnawir dan Basyiruddin, [1]). Metode Drill dilalui dengan dua fase: Pertama, fase integratif presepsi dari arti dan proses 
dkembangkan. Pada fase ini belajar kecakapan dikembangkan melalui praktek yang berarti sering melakukan hubungan fungsional dan aktifitas penyelidikan. Kedua, fase penyempurnaan atau fase penyelesaian, pada tahap ini ketelitian dapat dikembangkan menuntut praktek yang berulang kali.

Tenaga pendidik perlu mengubah pola pengorganisasian, kesempatan belajar dari bersifat didaktis kearah yang lebih bersifat individual. Artinya, tenaga pendidik perlu menjamin bahwa setiap peserta didik akan memperoleh pengetahuan dan keterampilan sesuai dengan tujuan pembelajarannya, serta memunculkan kesempatan yang sama bagi peserta didik untuk bersikap aktif mencari, memperoleh dan mengelola perolehan pembelajarannya.

Thomdike mengemukakan keaktifan siswa dalam belajar dengan hukum "law of exercise" yang menyatakan bahwa belajar memerlukan adanya latihan-latihan. Mc Keachie berkenan dengan prinsip keaktifan mengemukakan bahwa individu merupakan "manusia belajar yang aktif selalu ingin tahu, social" (Dimyati dan Mudjiono, [2]). Zuckerman meyakini bahwa belajar akan diperoleh melalui pengalaman, pembelajaran yang aktif dan dengan cara melakukan interaksi dengan bahan ajar maupun dengan orang lain (Warsono, [11]).

Perubahan-perubahan yang terjadi pada diri peserta didik menyangkut aspek kognitif, afektif dan psikomotorik merupakan sebagai hasil dari kegiatan belajar. Gagne juga mengemukakan bahwa penampilan-penampilan yang dapat diamati sebagai hasil-hasil belajar disebut kemampuan.

Beberapa riset telah dilakukan untuk mengetahui seberapa efektif model pembelajaran dapat mempengaruhi hasil belajar. Azlina [4] meneliti peningkatan proses pembelajaran kolaboratif yang dikenal sebagai model Think-Pair-Share, hasilnya kolaboratif Think-PairShare dapat meningkatkan hasil belajar. Volpe [9] meneliti mengenai pengenalan metode Drill, hasil yang diperoleh metode Drill lebih efisien untuk semua siswakarena meresponkondisi baik dalam pembelajaran.

\section{Metode Penelitian}

Metode penelitian ini adalah Quasi Experimental. Alasan dilakukannya penelitian eksperimental semu ini adalah tidak memungkinkannya bagi peneliti untuk mengendalikan dan memanipulasi semua variabel relevan yang dapat mempengaruhi hasil belajar matematika peserta didik. Penelitian ini menggunakan rancangan faktorial 2 x 3. Menurut Sudjana [7] desain ini dapat memberikan perlakuan dua variabel bebas atau lebih pada waktu yang bersamaan untuk melihat efek masing-masing yang terjadi akibat adanya interaksi beberapa variabel, seperti disajikan pada Tabel 1.

Tabel 1. Rancangan penelitian faktorial $2 \times 3$

\begin{tabular}{|c|c|c|c|}
\hline \multirow{2}{*}{$\mathbf{A}$} & \multicolumn{3}{|c|}{$\mathbf{B}$} \\
\cline { 2 - 4 } & $\mathbf{b}_{1}$ & $\mathbf{b}_{2}$ & $\mathbf{b}_{3}$ \\
\hline $\mathbf{a}_{1}$ & $\mathrm{a}_{1} \mathrm{~b}_{1}$ & $\mathrm{a}_{1} \mathrm{~b}_{2}$ & $\mathrm{a}_{1} \mathrm{~b}_{3}$ \\
\hline $\mathbf{a}_{2}$ & $\mathrm{a}_{2} \mathrm{~b}_{1}$ & $\mathrm{a}_{2} \mathrm{~b}_{2}$ & $\mathrm{a}_{2} \mathrm{~b}_{3}$ \\
\hline
\end{tabular}

Dimana:

A $\quad=$ Model pembelajaran

$\mathrm{a}_{1}=$ Kelas eksperimen satu yang menggunakan model pembelajaran kooperatif tipe

Think-Pair-Share berbantuan metode Drill

$\mathrm{a}_{2} \quad=$ Kelas eksperimen dua yang menggunakan Metode Drill

B = Keaktifan

$\mathrm{b}_{1} \quad=$ keaktifan tinggi

$\mathrm{b}_{2} \quad=$ keaktifan tinggi

$\mathrm{b}_{3} \quad=$ keaktifan tinggi 
Subjek penelitian sebanyak 2 kelas sebagai kelas eksperimen kesatu yaitu kelas VIII A dan kelas eksperimen kedua yaitu kelas VIII C.

Penelitian ini meneliti keterkaitan satu variabel terikat dengan satu variabel bebas dan satu variabel moderator. Variabel terikat pada penelitian ini adalah hasil belajar matematika, sedangkan model pembelajaran merupakan variabel bebas dan keaktifan adalah variabel moderator.

Prosedur yang dilakukan dalam penelitian adalah a) Penelitian diawali dengan menentukan subyek penelitian b) Menentukan langkah-langkah pembelajaran kooperatif tipe TPS berbantuan drill dan yang hanya menggunakan metodedrill yang dituangkan dalam rencana pelaksanaan pembelajaran (RPP) c) Menyusun kisi-kisi tes uji coba hasil belajar dan angket keaktifan e). Melakukan ujicoba tes hasil belajar pada kelas uji coba, f). Menganalisis data hasil uji coba untuk mengetahui validitas butir dan reliabilitas tes. Soal yang memenuhi syarat dijadikan soal posttest pada kelas pembelajaran kooperatif tipe TPS berbantuan metode drill dan yang hanya menggunakan metode drill, g). Melakukan validitas konstruk angket keaktifan. h). Melaksanakan pembelajaran sesuai dengan skenario pembelajaran i). Melaksanakan tes akhir posttest untuk mengukur hasil belajar peserta didik, j). Melakukan penyebaran angket keaktifan. k) Menganalisis data tes evaluasi yang diambil pada kelas pembelajaran kooperatif tipe TPS berbantuan metode drill dan yang hanya menggunakan metode drill, l). Menyusun hasil penelitian, m). Menarik kesimpulan berdasarkan hasil penelitian yang didapat.

Instrumen penelitian yang digunakan sebagai alat mengumpulkan data adalah dokumentasi, tes hasil belajar, angket dan lembar observasi. Analisis data untuk tes hasil belajar siswa diukur dengan 10 pertanyaan uraian yang telah di ujicoba pada kelas uji coba dengan menggunakan uji validitas dan uji reliabilitas. Uji validitas menggunakan product moment dan realiabilitas menggunakan alpha cronbach, diperoleh 9 soal uraian yang valid dan reliabilitas.

Angket keaktifan menggunakan validitas konstruk dengan pertimbangan ahli, dan reliabilitas dengan kesepakatan pengamat dengan jumlah butir penyataan 30 item.

Sebelum dilakukan uji hipotesis, dilakukan uji prasyarat yaitu normalitas dan homogenitas.

Uji normalitas mengunakan lillifors. Hipotesis statistiknya adalah :

Ho : sampel berasal dari populasi berdistribusi normal;

$\mathrm{H}_{1}$ : sampel berasal dari populasi berdistribusi tidak normal.

Jika Lhitung $\leq \mathrm{L}_{\text {tabel }}$ maka $\mathrm{H}_{\mathrm{o}}$ diterima artinya distribusi data dapat dikatakan nomal dan sebaliknya.

Uji homogenitas mengunakan Fisher. Hipotesis statistiknya adalah :

Ho : sampel berasal dari populasi homogen;

$\mathrm{H}_{1}$ : sampel berasal dari populasi tidak homogen.

Jika $\mathrm{F}_{\text {hitung }} \leq \mathrm{F}_{\text {tabel }}$ maka $\mathrm{H}_{\mathrm{o}}$ diterima artinya distribusi data dapat dikatakan homogen dan sebaliknya.

Analisis data eksperimen penelitian ini menggunakan analisis varians dua jalan dengan sel tak sama untuk menguji pengaruh model terhadap hasil belajar $\left(\mathrm{H}_{\mathrm{oA}}\right)$, pengaruh kategori keaktifan $\left(\mathrm{H}_{\mathrm{oB}}\right)$ dan interaksi model pembelajaran, kategori keaktifan terhadap hasil belajar $\left(\mathrm{H}_{\mathrm{OAB}}\right)$. Untuk $\mathrm{H}_{0 \mathrm{~A}}$ dan $\mathrm{H}_{0 \mathrm{~B}}$, jika $\mathrm{F}_{0 \mathrm{~A}}$ hitung $>$ Ftabel maka Ho ditolak, Jika $\mathrm{F}_{0 \mathrm{~B}}$ hitung $>$ Ftabel maka Ho ditolak. Maka terdapat perbedaan rata-rata antar kelompok yang diuji untuk Interaksi $\mathrm{H}_{\mathrm{OAB}}$ 
Jika $\mathrm{F}_{(\mathrm{OAB})}>$ Ftabel atau Ho ditolak maka terdapat pengaruh interaksi yang signifikan.

Sedangkan uji keseimbangan menggunakan anava satu jalan dilakukan sebelum uji lanjut pasca anava untuk menguji beda rerata sel pada masing-masing kelas eksperimen.

Jika $F_{\text {hitung }}>F_{\text {tabel }}$ pada taraf signifikan $a=0,05$ dengan db pembilang adalah $\mathrm{db}(\mathrm{By})$ dan $\mathrm{db}$ penyebut adalah db (Dy) maka Ho ditolak.Maka terdapat perbedaan rata-rata parameter antara kelompok-kelompok keaktifan yang diuji.

Untuk tahap terakhir yaitu uji lanjut pasca analisis varians dilakukan Uji komparasi ganda, merupakan uji tindak lanjut dari analisis variansi apabila hasil analisis variansi menujukkan bahwa hipotesis nol ditolak. Dalam penelitian ini, uji lanjutan setelah analisis variansi digunakan uji lanjut dengan $t$-Dunnet. Alasan digunakan uji lanjut dengan $t$ - Dunnet karena metode ini mampu menghasilkan beda rerata dengan tingkat signifikan yang kecil. Kriteria Pengujian jika $\mathrm{T}_{\text {hitung }}>\mathrm{T}_{\text {tabel }}$ maka $\mathrm{H}_{0}$ ditolak.

\section{Hasil dan Pembahasan}

Data tes hasil belajar matematika diperoleh untuk rata-rata kelas eksperimen pertama atau pada siswa-siswa yang diberi model TPS berbantuan metode Drill adalah 82,48 dengan perolehan nilai tertinggi yaitu 100 dan nilai terendah yaitu 62 . Sedangkan rata-rata kelas eksperimen kedua atau pada siswa-siswa yang hanya diberi metode Drill adalah 72,08 dengan perolehan nilai tertinggi yaitu 96 dan nilai terendah yaitu 48 .

Berdasarkan perolehan data keaktifan, dari 29 siswa dari kelas eksperimen pertama, terdapat 8 siswa yang termasuk kategori tinggi, 16 siswa termasuk kategori sedang dan 5 siswa termasuk dalam kategori rendah. Kelas eksperimen kedua, terdapat 8 siswa yang termasuk kategori tinggi, 22 siswa termasuk kategori sedang dan 7 siswa termasuk dalam kategori rendah.

Tabel 2. Hasil belajar matematika siswa berdasarkan model pembelajaran dan keaktifan belajar

\begin{tabular}{|c|c|c|c|}
\hline \multirow[b]{2}{*}{ A } & \multicolumn{3}{|c|}{ Keaktifan Belajar Siswa } \\
\hline & $\begin{array}{l}\text { Tinggi } \\
\text { (b1) }\end{array}$ & Sedang $\left(b_{2}\right)$ & $\begin{array}{c}\text { Rendah } \\
\left(b_{3}\right)\end{array}$ \\
\hline $\begin{array}{c}\text { Model TPS } \\
\text { berbatuan } \\
\text { metode } \\
\text { Drill (a1) }\end{array}$ & $\begin{array}{l}82,96 \\
100,98 \\
88,98 \\
88,98\end{array}$ & $\begin{array}{l}70,78,77,65,84, \\
77,88,81,69,88, \\
98,89,90,75,87, \\
96\end{array}$ & $\begin{array}{l}70,62, \\
66,72,62\end{array}$ \\
\hline $\begin{array}{c}\text { Metode } \\
\text { Drill (a2) }\end{array}$ & $\begin{array}{l}96,96 \\
83,88 \\
96,58 \\
78,80\end{array}$ & $\begin{array}{l}83,78,60,86,86, \\
74,80,68,78,50, \\
90,88,88,64,48, \\
50,48,48,79,74, \\
86,50\end{array}$ & $\begin{array}{l}50,60, \\
68,60, \\
64,50,84\end{array}$ \\
\hline
\end{tabular}

Uji normalitas dimaksudkan untuk mengetahui apakah sampel berasal dari populasi yang berdistribusi normal atau tidak. Dari Tabel 3 tampak bahwa harga statistik uji (L hit) masing-masing kategori tidak melebihi L 0,05;n atau L tabel. Dengan demikian keputusan yang diambil adalah H0 tidak ditolak (diterima) atau sampel berasal dari populasi berdistribusi normal.

Hasil uji homogenitas dengan metode Fisher disajikan pada Tabel 4. tampak bahwa harga statistik uji (F hit) masing-masing kategori tidak melebihi $\mathrm{F}_{(0,05)(\text { dbpembilang : dbpenyebut) }}$ atau 
F tabel. Dengan demikian keputusan yang diambil adalah $\mathrm{H}_{0}$ tidak ditolak (diterima) atau sampel berasal dari populasi yang homogen.

Hasil perhitungan analisis variansi dua jalan dengan sel tak sama disajikan pada Tabel 5 menunjukkan bahwa : a) Pada efek utama baris (A) $\mathrm{H}_{0}$ ditolak. Hal ini berarti siswa yang diberi model pembelajaran TPS berbantuan drill mempunyai hasil belajar matematika yang berbeda dengan siswa yang hanya diberi metode drill, artinya model pembelajaran berpengaruh terhadap hasil belajar matematika pada pokok bahasan kubus dan balok. b) Pada efek utama kolom (B) $\mathrm{H}_{0}$ ditolak. Hal ini berarti kategori keaktifan belajar siswa memberikan pengaruh terhadap hasil belajar matematika pada pokok bahasan kubus dan balok. c) Pada efek utama interaksi (AB) HO ditolak. Hal ini berarti terdapat interaksi antara model pembelajaran dengan keaktifan belajar siswa terhadap hasil belajar matematika

Hasil uji keseimbangan yaitu pada tabel 6tampak bahwa harga statistik uji (F hit) masing-masing kategori keaktifan lebih besar dari $\mathrm{F}_{(0,05 ; 5 ; 60)}$ atau $\mathrm{F}$ tabel. Dengan demikian keputusan yang diambil adalah H0 ditolak atau dengan demikian terdapat perbedaan ratarata antar keenam kelompok(sel).

Berdasarkanperhitungan analisis variansi dua jalan sel tak sama telah diperoleh keputusan uji bahwa $\mathrm{H}_{0} \mathrm{~A}, \mathrm{H}_{0} \mathrm{~B}$, dan $\mathrm{H}_{0} \mathrm{AB}$ ditolak, maka untuk selanjutnya uji yang dilakukan adalah sebagai berikut:

1). Simple effect antar baris diperoleh dari hasil analisis variansi dua jalan dengan sel tak sama yang terangkum dalam tabel 5 diperoleh H0A ditolak, ini berarti kategori model pembelajaran memberikan pengaruh yang berbeda terhadap hasil belajar matematika siswa pokok bahasan kubus dan balok dan karena variabel model pembelajaran hanya memiliki dua kategori maka tidak perlu dilakukan uji lanjut anava atau simple effect.

2). Hasil perhitungan uji simple effect antar kolom disajikan dalam Tabel 7 menunjukkan bahwa : a). Untuk masing-masing model pembelajaranTPS berbantuan metode Drill dan yang hanya menggunakan metode Drill, hasil belajar matematika kelompok siswa dengan keaktifan tinggi lebih baik dari pada kelompok siswa keaktifan sedang. b). Untuk masing-masing model pembelajaranTPS berbantuan metode Drill dan yang hanya menggunakan metode Drill, hasil belajar matematika kelompok siswa dengan keaktifan tinggi lebih baik dari pada kelompok siswa keaktifan rendah. c) Untuk masing-masing model pembelajaran TPS berbantuan metode Drill dan yang hanya menggunakan metode Drill, hasil belajar matematika kelompok siswa dengan keaktifan sedang lebih baik dari pada kelompok siswa keaktifan rendah.

3). Hasil perhitungan simple effectantar sel disajikan dalam Tabel 8 menunjukkan bahwa : a). Tidak terdapat perbedaan hasil belajar matematika yang menggunakan model kooperatif think-pair-share berbantuan metode drill dan yang hanya menggunakan metode drill untuk kelompok siswa dengan keaktifan tinggi. b). Hasil belajar matematika yang menggunakan model kooperatif think-pair-share berbantuan metode drill lebih baik daripada yang hanya menggunakan metode drill untuk kelompok siswa dengan keaktifan sedang. c) Tidak terdapat perbedaan hasil belajar matematika yang menggunakan model kooperatif think-pair-share berbantuan metode drill dan yang hanya menggunakan metode drill untuk kelompok siswa dengan keaktifan rendah.

Tabel 3. Hasil analisis uji normalitas

\begin{tabular}{|c|c|c|c|c|c|}
\hline Sumber & $\mathbf{N}$ & $\mathbf{L}_{\text {hitung }}$ & $\mathbf{L}_{\text {tabel }}$ & Keputusan & Kesimpulan \\
\hline $\begin{array}{c}\text { Kelas Eksperimen } \\
1 \text { (model TPS } \\
\text { berbantuan Drill) }\end{array}$ & 29 & 0.094888 & 0,161 & H0 diterima & Normal \\
\hline $\begin{array}{c}\text { Kelas Eksperimen } \\
2 \text { (Drill) }\end{array}$ & 37 & 0.134673 & 0.145657 & H0 diterima & Normal \\
\hline
\end{tabular}


Tabel 4. Hasil analisis uji homogenitas

\begin{tabular}{|c|c|c|c|c|c|c|}
\hline Sumber & $\mathbf{N}$ & Varians & $F_{\text {hitung }}$ & $F_{\text {tabel }}$ & Keputusan & Kesimpulan \\
\hline $\begin{array}{c}\text { Kelas } \\
\text { Eksperimen } 1 \\
\text { (model TPS } \\
\text { berbantuan Drill) }\end{array}$ & 29 & 144.168 & \multirow{2}{*}{1,738} & \multirow{2}{*}{1,81} & \multirow{2}{*}{ H0 diterima } & \multirow{2}{*}{ Homogen } \\
\hline $\begin{array}{c}\text { Kelas } \\
\text { Eksperimen } 2 \\
\text { (Drill) }\end{array}$ & 37 & 250.620 & & & & \\
\hline
\end{tabular}

Tabel 5. Rangkuman analisis variansi dua jalan dengan sel tak sama

\begin{tabular}{|c|c|c|c|c|c|c|}
\hline $\begin{array}{l}\text { Sumber } \\
\text { Varians }\end{array}$ & JK & Db & RJK & $\mathbf{F}_{\text {hitung }}$ & $\begin{array}{l}F_{\text {tabel }} \\
\alpha=0,05\end{array}$ & keputusan \\
\hline Model (A) & 4388,5788 & 1 & 4388,5788 & 49,19 & 4,00 & Ho ditolak \\
\hline $\begin{array}{l}\text { Keaktifan } \\
\text { (B) }\end{array}$ & 1758,9918 & 2 & 879,49593 & 9,85 & 3,15 & Ho ditolak \\
\hline $\begin{array}{c}\text { Interaksi } \\
\text { AxB }\end{array}$ & 3318,5357 & 2 & 1659,26785 & 18,59 & 3,15 & Ho ditolak \\
\hline Dalam & 5352,8787 & 60 & 89,214645 & 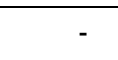 & - & \\
\hline Total & 14818,985 & 65 & - & - & - & \\
\hline
\end{tabular}

Tabel 6. Hasil prosedur variansi satu jalan

\begin{tabular}{|c|c|c|c|c|c|c|}
\hline $\begin{array}{l}\text { Sumber } \\
\text { varians }\end{array}$ & JK & Db & RJK & $F_{\text {hitung }}$ & $\begin{array}{c}F_{\text {tabel }} \\
\alpha=0,05\end{array}$ & Keputusan \\
\hline Keaktifan & 5948,1227 & 5 & 1189,62454 & \multirow{3}{*}{8,046} & \multirow{3}{*}{2,37} & \multirow{3}{*}{ Ho ditolak } \\
\hline Dalam & 8870,8623 & 60 & 147,847705 & & & \\
\hline Total & 14818,985 & 65 & - & & & \\
\hline
\end{tabular}

Tabel 7. Hasil uji komparasi ganda antar kolom

\begin{tabular}{|c|c|c|c|c|}
\hline \multirow[b]{2}{*}{ Kategori Keaktifan } & \multicolumn{2}{|c|}{$t_{\text {hit }}$} & \multirow[b]{2}{*}{$t_{\text {tabel }}$} & \multirow[b]{2}{*}{ Keputusan } \\
\hline & $\begin{array}{c}\text { Model TPS } \\
\text { berbantuan } \\
\text { Metode Drill }\end{array}$ & $\begin{array}{c}\text { Metode } \\
\text { Drill }\end{array}$ & & \\
\hline Tinggi vs Sedang & 2,11 & 2,71 & \multirow{3}{*}{1,671} & Ho ditolak \\
\hline Tinggi vs Rendah & 3,85 & 3,51 & & Ho ditolak \\
\hline Sedang vs Rendah & 4,39 & 1,71 & & Ho ditolak \\
\hline
\end{tabular}

Tabel 8. Hasil uji komparasi ganda antar sel

\begin{tabular}{|c|c|c|c|}
\hline \multirow{2}{*}{ Keaktifan } & thit & \multirow{2}{*}{t$_{\text {tabel }}$} & Keputusan \\
\cline { 2 - 2 } & Model Pembelajaran & & \\
\hline Tinggi & 1,442 & \multirow{2}{*}{1,671} & Ho diterima \\
\hline Sedang & 2,82 & Ho ditolak \\
\hline Rendah & 0,57 & & Ho diterima \\
\hline
\end{tabular}

\section{Simpulan}

Hasil belajar matematika siswa yang mengikuti pembelajaran matematika dengan model pembelajaran kooperatif tipe Think-Pair-Share berbantuan metode Drill lebih baik daripada hasil belajar matematika siswa yang mengikuti pembelajaran hanya dengan metode Drill pada pokok bahasan kubus dan balok siswa kelas VIII semester II SMP YAPIA Ciputat tahun ajaran 2014/2015. 
Keaktifan belajar siswa memberikan pengaruh terhadap hasil belajar matematika pada pokok bahasan kubus dan balok. Untuk masing masing model pembelajaran kooperatif tipe Think-Pair-Share berbantuan metode Drill dan yang hanya menggunakan metode Drill, siswa yang memiliki keaktifan belajar matematika tinggi mempunyai hasil belajar yang lebih baik dibandingkan siswa yang mempunyai keaktifan belajar matematika sedang. Siswa yang memiliki keaktifan belajar tinggi mempunyai hasil belajar yang lebih baik dibandingkan dengan siswa yang mempunyai keaktifan belajar rendah. Siswa yang memiliki keaktifan belajar sedang mempunyai hasil belajar yang lebih baik dibandingkan dengan siswa yang mempunyai keaktifan belajar rendah.

Terdapat interaksi antara model pembelajaran dengan keaktifan belajar siswa terhadap hasil belajar matematika pada pokok bahasan kubus dan balok. Hasil belajar matematika siswa model pembelajaran kooperatif tipe Think-Pair-Share berbantuan metode Drill dan yang hanya menggunakan metode Drill untuk siswa yang memiliki keaktifan tinggi sama baiknya. Hasil belajar matematika siswa yang memiliki keaktifan sedang lebih baik meenggunakan model pembelajaran kooperatif tipe Think-Pair-Share berbantuan metode Drill daripada yang hanya menggunakan metode Drill. Hasil belajar matematika siswa model pembelajaran kooperatif tipe Think-Pair-Share berbantuan metode Drill dan yang hanya menggunakan metode Drill untuk siswa yang memiliki keaktifan rendah sama baiknya.

Saran yang dapat disampaikan yaitu: 1) Guru dapat menggunakan model TPS berbantuan drill sebagai salah satu alternatif untukmenyampaikan pokok bahasan kubus dan balok, yang diharapkantepat untuk meningkatkan keaktifan belajar siswa sehingga siswa memperoleh hasil belajaryang tinggi. 2) Siswa hendaknya lebih memperhatikan dan segera bertanya kepada teman atau guru jika mengalami kesulitan. 3) Dalam penelitian ini model pembelajaran ditinjau dari keaktifan belajar matematika siswa. Bagi para calon peneliti yang lain mungkin dapat melakukan tinjauan yang lain, misalnya kemampuan awal, kedisiplinan, gaya belajar, karakteristik cara berpikir, kreativitas, minat siswa, intelegensi dan lain-lain agar dapat lebih mengetahui faktor-faktor yang mempengaruhi hasil belajar matematika siswa.

\section{Daftar Pustaka}

[1]. Asnawir, dan Basyiruddin Usman. 2002. Media Pembelajaran. Jakarta:Ciputat Pers

[2]. Dimyati dan Mudjiono. 2013. Belajar dan Pembelajaran. Jakarta: Rineka Cipta

[3]. Faizi, Mastur. 2013. Ragam Metode Mengajarkan Eksakta pada Murid. Yogyakarta: Diva Press

[4]. N, A,. Nik Azlina. 2010. Supporting Collaborative Activities Among Students and Teachers Through the Use of Think-Pair-Share Techniques. IJCSI International Journal of Computer Science Issues, Vol. 7, Issue 5. pp. 19

[5]. Sanjaya, Wina. 2006. Strategi Pembelajaran Orientasi Standart Proses Pendidikan. Jakarta: Kencana

[6]. Slavin, Robert. 2009. Cooperative Learning (teori, riset dan praktik). Bandung: Nusa Media

[7]. Sudjana, Nana. 2007. Penelitian dan Penilaian Pendidikan. Jakarta: Sinar Baru Algesindo

[8]. Trianto. 2009. Mendesain Model Pembelajaran Inovatif-Progresif. Jakarta: Kencana

[9]. Volpe, Robert J.; Mule, Christina M.; Briesch, Amy M.; Joseph, Laurice M.; Burns,

[10]. Matthew K. 2011. A Comparison of Two Flashcard Drill Methods Targeting Word RecognitionJournal of Behavioral Education, v20 n2 p117-137

[11].Warsono. 2012. Pembelajaran Aktif Teori dan Asesment. Bandung: PT Remaja Rosdakarya

[12].Yamin, Martinis. 2012. Desain Baru Pembelajaran Kontruktivistik. Jakarta: Referensi 